\title{
Dynamics of consumer expenditure and stock market prices and uncertainty: Malaysian evidence
}

\begin{abstract}
The present paper analyzes the role of stock market, more specifically real stock prices and stock market uncertainty/volatility, on private consumption behavior for an emerging market, Malaysia, using quarterly data from 1991 to 2009. Employing the autoregressive distributed lag approach to cointegration test, the paper establishes a long-run equilibrium that ties private consumption to its determinants $\partial$ real income, real stock prices, real lending rate, and stock market volatility. In the long run, the presence of the stock market wealth effect is documented. At the same time, the stock market volatility is also noted to depress private consumption particularly when the volatility is at the degree as observed during the Asian crisis. The authors further note the short-run influences of real stock price changes on consumption growth and the adjustment of private consumption to the long-run level when it is modeled in an error-correction setting. Our simple simulation indicates that the drop in the private consumption due to the decline in stock market wealth post-crisis is substantial, amounting to $2.7 \%$ of average post-crisis gross domestic product.
\end{abstract}

Keyword: Conditional and realized volatility; Malaysia; Private consumption; Stock market wealth 